\title{
Proposal to Place the Nomenclature of the Cyanobacteria (Blue-Green Algae) Under the Rules of the International Code of Nomenclature of Bacteria
}

\author{
R. Y. STANIER, ${ }^{1}$ W. R. SISTROM, ${ }^{2}$ T. A. HANSEN, ${ }^{3}$ \\ B. A. WHITTON, ${ }^{4}$ R. W. CASTENHOLZ, ${ }^{5}$ N. PFENNIG, \\ V. N. GORLENKO ${ }^{7}$ E. N. KONDRATIEVA, ${ }^{8}$ K. E. EIMHJELLEN, ${ }^{9}$ \\ R. WHITTENBURY, ${ }^{10}$ R. L. GHERNA," AND H. G. TRÜPER ${ }^{12}$
}

\begin{abstract}
Institut Pasteur, 25 rue du Docteur Roux, Paris 15e, France'; Department of Biology, University of Oregon, Eugene, Oregon 97403'; Laboratorium voor Microbiologie, University of Groningen Biology Center, Haren (Gr.), The Netherlands; ; Department of Botany, University of Durham, South Road, Durham, England ${ }^{4}$; Department of Biology, University of Oregon, Eugene, Oregon 97403'; Institut für Mikrobiologie der Universität, Grisebachstrasse 8, D-3400 Göttingen, Federal Republic of Germany ; Institute of Microbiology, U.S.S.R. Academy of Sciences, Profsojuznaya 7, Moscow B 135, U.S.S.R. ${ }^{7}$; Department of Microbiology, Moscow State University, Moscow B 234, U.S.S.R. ${ }^{8}$; Department of Biochemistry, Technical University of Norway, N-7034 Trondheim, Norway"; Department of Biological Sciences, University of Warwick, Coventry, Warwichshire CV4 7AL, England ${ }^{10}$; American Type Culture Collection, 12301 Parklawn Drive, Rockville, Maryland 20852 ${ }^{11}$; Institut für Mikrobiologie der Universität, Meckenheimer Allee 168, D-5300 Bonn, Federal Republic of Germany ${ }^{12}$
\end{abstract}

The Subcommittee on the Phototrophic Bacteria of the International Committee on Systematic Bacteriology (ICSB) of the International Association of Microbiological Societies (IAMS) proposes unanimously to the ICSB that the nomenclature of the cyanobacteria (cyanophytes, blue-green algae) shall be governed as of 1 January 1979 by the provisions of the International Code of Nomenclature of Bacteria (3). Since a prospective date (1 January 1980) has been fixed for the publication of approved lists of procaryotic names, it is further recommended that this deadline should be extended, in the particular case of the cyanobacteria, to 1 January 1985.

The organisms termed blue-green algae or cyanophytes by botanists and blue-green bacteria or cyanobacteria by bacteriologists have long been classified as a major taxon (class or division) among the algae. This interpretation of their place in the biological world appeared reasonable until about 1960, when the fundamental differences between procaryotes and eucaryotes with respect to the organization of the cell could at last be clearly and precisely defined $(4,6,7)$. Two taxonomically significant facts then became evident: the blue-green algae are typical procaryotes in terms of their cellular properties; and the procaryotic structure of the cell constitutes the only set of properties common to, and distinctive of, all bacteria. These properties are accordingly fundamental to the definition of bacteria as a major biological assemblage: "bacterium" and "procaryote" are synonymous terms.

In 1974, these taxonomic conclusions were made explicit by the editors of the eighth edition of Bergey's Manual of Determinative Bacteriology (1), the standard treatise on the classification of bacteria. The bacteria were treated as members of the kingdom Procaryotae, composed of two divisions: "I The Cyanobacteria" and "II The Bacteria." An even closer taxonomic integration of the cyanobacteria is proposed (2) for the next edition of Bergey's Manual: they will be united with other photosynthetic procaryotes in a single class, the photobacteria.

No formal proposal has so far been made to take an action that is a logical corollary of the recognition of the cyanobacteria as a major bacterial taxon: namely, to place their nomenclature under the rules of the Bacteriological Code (3). As long as the taxonomic analysis of cyanobacteria was based on the determination of structural properties of natural populations, the provisions of this Code remained largely inapplicable. However, the increasing availability of axenic cultures of cyanobacteria has now opened the way to taxonomic analyses of these organisms by the standard techniques of bacterial taxonomy, utilizable only with axenic material.

The nomenclatural cornerstone of bacterial taxonomy is the type strain, which defines both species and (through type species) genus. The Botanical Code (5) does not recognize cultures as nomenclatural types, and the nonliving botanical type materials (herbarium specimens, descriptions, and illustrations) are immutable. For 
the purposes of a bacterial taxonomist, it is seldom that much useful information can be extracted from a herbarium specimen; the only additional information provided by most existing descriptions and illustrations of cyanobacterial types is ecological. Consequently, a bacterial taxonomist cannot work effectively under the rules of the Botanical Code. Even if he can define a species by both genetic and phenetic criteria on the basis of culture studies, he may be unable to name it for want of satisfactory nomenclatural points of reference.

Recognition of this problem in bacterial groups such as the myxobacteria, where many holotypes were represented initially by herbarium specimens, has led to the introduction into the Bacteriological Code of a Rule (18h) permitting the later replacement of nonliving type materials by strains (represented by living cultures), which then acquire the status of holotypes. We believe that the application, whenever possible, of this Rule (which has of course no counterpart in the Botanical Code) is essential for the development of a stable system of cyanobacterial nomenclature that can be used in conjunction with taxonomic analyses of cultural material.

A prospective date (1 January 1980) has been fixed as the point of departure for nomenclatural priority of bacteria. Even if the cyanobacteria could be brought under the Bacteriological Code without undue delay, it would not be possible by this date to carry through the very complex task of nomenclatural revision and publication of a list of approved names.

The Subcommittee on the Phototrophic Bacteria of the ICSB of the IAMS therefore unani- mously submits to the ICSB the following proposal:

As of 1 January 1979, the nomenclature of cyanobacteria ("blue-green algae") shall be governed by the provisions of the International Code of Nomenclature of Bacteria. The deadline for publication of approved lists of names for these procaryotes should be extended to 1 January 1985 .

\section{REPRINT REQUESTS}

Address reprint requests to: $R$. Y. Stanier, Institut Pasteur, 25 rue du Docteur Roux, Paris $15 e$, France.

\section{LITERATURE CITED}

1. Buchanan, R. E., and N. E. Gibbons (ed.). 1974. Bergey's manual of determinative bacteriology. The Williams \& Wilkins Co., Baltimore.

2. Gibbons, N. E., and R. G. E. Murray. 1978. Proposals concerning the higher taxa of bacteria. Int. J. Syst. Bacteriol. 28:1-6.

3. Lapage, S. P., P. H. A. Sneath, E. F. Lessel, V. B. D. Skerman, H. P. R. Seeliger, and W. A. Clark (ed.). 1975. International code of nomenclature of bacteria. American Society for Microbiology, Washington, D.C.

4. Murray, R. G. E. 1962. Fine structure and taxonomy of bacteria, p. 119-144. In G. C. Ainsworth and P. H. A. Sneath (ed.), Microbial classification. 12th Symposium of the Society for General Microbiology. Cambridge University Press, Cambridge, England.

5. Stafleu, F. A., C. E. B. Bonner, R. McVaugh, R. D. Meikle, R. C. Rollins, R. Roff, J. M. Schops, G. M. Schulze, R. De Vilmorin, and E. G. Voss. 1972. International code of botanical nomenclature. A. Oosthoek, Utrecht.

6. Stanier, R. Y. 1961. La place des bactéries dans le monde vivant. Ann. Inst. Pasteur (Paris) 101:297-312.

7. Stanier, R. Y., and C. B. van Niel. 1962. The concept of a bacterium. Arch. Mikrobiol. 42:17-35. 